\title{
The Influence of Russian Music Culture on Harbin Piano Music Culture
}

\author{
Jiang Chen \\ Heihe College, Heihe Heilongjiang 164300
}

Keywords: Music Culture in Heilongjiang; Russia

\begin{abstract}
This paper takes the 20th century Russian music culture to Heilongjiang music culture influence as the research object. From the instrumentalization, vocalization, family music education, general school education, professional school education and other dimensions to cut into. This paper sorts out and studies its positive cultural impact, in order to achieve the purpose of drawing lessons from the excellent traditional Russian music culture and promoting the construction of Heilongjiang music culture.
\end{abstract}

\section{Introduction}

As a neighbour of our country, Russia has a long border with our province of Heilongjiang. At the end of the 18th century, due to the corruption and incompetence of the Qing government, the Czar Russia had an opportunity to invade our country from the political, military, economic, cultural and other aspects. Its influence on Heilongjiang is particularly huge. Objectively speaking, Heilongjiang had become a typical semi feudal and semi colonial province at that time. This process came to an end until the "918" incident in 1931. After the founding of New China in 1949, due to the special historical and international situation, China maintained close exchanges with the former Soviet Union for nearly a decade, during which Heilongjiang, as the bridgehead province of exchanges at that time, played a very important role as a bridge for all-round exchanges. Heilongjiang's economic, technological, cultural and other aspects have been affected by the former Soviet Union. With the disintegration of the Soviet Union after the reform and opening up, after the establishment of the Republic of the Russian Federation, Heilongjiang and Russia's economy, science and technology, culture and other aspects have entered a higher and deeper level of comprehensive exchanges. From the above analysis, it can be seen that Heilongjiang has maintained a very close and comprehensive exchange relationship with Russia in three stages in the past century, and this exchange relationship only had a brief interruption in the 1960s and 1970s. This communication can be said to have penetrated into all fields of society. Among them, the influence of cultural field on Heilongjiang is more significant and the time span of influence is longer. Among them, the influence of music culture is the most representative.

\section{Instrumental Music Influence}

Russia as a country across the Eurasian continent, its cultural center is mainly in its European 
part, so the main body of Russian music culture embodies the characteristics of European music culture. Instrumental music plays an important role in music culture. This is particularly evident in the popularity of symphony and Russian instrumental music. The characteristic instruments, especially the keyboard, are the most outstanding. Accordion education can be said to be popular all the time. In the 1980s, most of the objects of music enlightenment and music education in Heilongjiang and even the whole Northeast China started from accordion playing and teaching. Accordion performance and teaching occupied an important position in Heilongjiang music education for a long time. A large number of outstanding accordion performers, such as Song Liquan and Wang Hongyu, were trained and emerged. This discipline advantage has been maintained until now. At present, international and domestic accordion high-end competitions are often held in Harbin. At the same time, the popularization of basic accordion teaching in Heilongjiang is also in full swing. There are many junior middle schools and senior middle schools in various cities to cultivate accordion artistic expertise as a dominant discipline. In addition to the accordion, Russian orchestra also has a very prominent advantage in this subject in the world, especially in trumpet, Violin and other skills more complex instruments, Russia for Heilongjiang music education has had a great impact. In the 1920s, Russian musicians exiled to Harbin spontaneously organized orchestras of different sizes. The most famous orchestra was the Harbin East Qing Railway Administration Symphony Orchestra, which was established by Russian expatriates (Belarus) living in Harbin in April 1908. During the heyday of the 20th and 30th generations of the last century, this orchestra was once called the Far East First Symphony Orchestra, and later called the old "Kazakhstan Symphony Orchestra". This Orchestra trained the first instrumental talents for Heilongjiang Province. Many of the teachers who later taught in Shenyang Conservatory of Music, Jilin Art College, Harbin Normal University and Heilongjiang University were instructed or directly participated in the performance of the Russian Orchestra. These Chinese musicians went to college music classes and passed on all the knowledge to Chinese students, so that the Russian instrumental music culture further spread in Heilongjiang.

\section{The Influence of Vocal Culture}

Russian art songs occupy an important position in its national music, its melody is beautiful, rhythm is full of rhythm, accompaniment texture is exquisite. Tchaikovsky, Glinka, Stravinsky and other Russian composers. A large number of world-renowned Russian art songs have been created. These artistic songs have a profound influence on Heilongjiang music education in both artistic and technical aspects. This influence is manifested in two aspects: on the one hand, many art performers regard Russian art songs as the classical repertoire of performances, and effectively spread Russian art songs; on the other hand, normal universities (Harbin Normal University, Mudanjiang Normal University) and professional art colleges and Universities (the Harbin Conservatory of Music) takes Russian art songs as a feature of singing and teaching. Through the Harbin Summer International Music Festival and other carriers, Russian art songs in primary schools, secondary schools, universities and comprehensive dissemination, thus from a creative, secondary creative and other dimensions of in-depth impact on Heilongjiang music education.

\section{The Impact of Family Music Education}

The Russian nation is good at singing and dancing, and its rich music culture, to a great extent, benefits from its strong family music education atmosphere. Russian families attach great importance to the cultivation of musical literacy of the next generation, focusing on the art of nurturing children in daily life. In family life, family music teachers are often employed to teach children piano, vocal music, orchestral music and other activities, so that children receive 
systematic and professional education, but also often take their children to participate in symphonic concerts, watch ballet performances and other social music activities. The demonstrative role of Russian family music education has been shown for a long time. Since the 1920s, many middleclass families in Harbin have followed suit, hiring Russian professional music teachers to carry out professional music education for their children. A number of Chinese children have received systematic and professional music education. These children grew up to be the backbone of music performance and teaching in Northeast and even China.

\section{Influence of General Music Education}

The music education of ordinary schools in Heilongjiang is influenced by the convergence of local culture, Japanese music culture and Russian music culture. Among them, Russian music culture is among the influences of foreign music culture. Occupy an important position. General music education in Heilongjiang is influenced by Russian language.

\subsection{Russian education goes deep into ordinary school education.}

Russian plays an important role in Heilongjiang's general school education. Especially in the first half of the 20th century, influenced by Russia and the Soviet Union, almost every secondary and ordinary school has set up Russian classes, the atmosphere of social learning Russian is very strong. In Russian teaching, in order to enable students to better grasp the language and feel the context through grammar, many teachers adopt the teaching of Russian songs as auxiliary language. Speech teaching. So a large number of Russian Songs spread on campus, and then spread to the society through the campus.

\subsection{Russian instrumental music teaching goes deep into ordinary school education}

In the 1920s, as a large number of Russian (Belarusian) children entered Chinese ordinary schools for education, they brought Western instrumental music, which was not very familiar to Chinese students, to the campus. Objectively, the external environment has given impetus to music education in ordinary schools, especially instrumental music education. Russian keyboard accordion has become popular in schools, and some middle schools have organized their own small orchestras.

\subsection{Russian music teaching mode was introduced into Heilongjiang.}

In 1950s, the mode of music education in ordinary schools in the Soviet Union was also spread to Heilongjiang. Ordinary music education in Russia is often implemented by compulsory means. The whole curriculum contains two major parts, one is professional basic knowledge, the other is professional skills content. The school system is from primary school to junior high school for nine years. This model has been used for reference in music education of primary and secondary schools in Heilongjiang Province, and has established a training mode combining professionalism with professionalism. However, judging from the popularization of music and the cultivation atmosphere of schools as a whole, the music education atmosphere of ordinary schools in China is still too weak. We should further strengthen the development of music education in ordinary schools, learn from the systematic and advanced nature of Russian music education and teaching system, and further promote the nationalization of music elements in our society. 


\section{The Impact of Professional Music Education}

In the 1920s, with the outbreak of the October Revolution of the Soviet Union, a large number of Soviet expatriates immigrated to Harbin. Among them were a group of musicians who were worldrenowned in Russia. Including the famous Russian pianist educator Gerschgorina, violin player Trakhginberg, famous singer DobrotVolskaya and so on. These musicians not only pay attention to the artistic expression of music, but also pay attention to the comprehensive training of music skills. Their arrival brought the most advanced performing and singing skills into Heilongjiang, greatly promoting the advanced evolution and internationalization of Heilongjiang music skills. At the same time, the Russian overseas Chinese also attach great importance to the establishment of systematic music education, and have established more than 30 professional music schools in Harbin, the most famous of which was established in May 1921, Harbin First College of Music, which is the first formal modern music school in China. This music school has followed the teaching mode and personnel training objectives of Royal College of Music in Russia. The school system lasted for six years; in July 1925, Russian nationals established the Harbin Grazunov School of Music in Harbin. In addition to offering professional courses in music, the school also offered theoretical courses in art history and music history so as to cultivate talents for complex music performance and music education; in October 1927, the church was established with Russian nationals. Harbin Music Training Course, this training course mainly to Western religious music as the teaching content, to recruit Russian children, training girls as the characteristics of enrollment; Harbin Music Training Course and Harbin First College of Music in 1948 merged to establish Harbin College of Music, Harbin Music in 1929 The school is set up. These four music schools established by Russian overseas Chinese have greatly promoted the process of music specialization education in Heilongjiang and even the whole of China. They have introduced advanced concepts of professional music education, teaching courses, performing skills and aesthetic concepts into Heilongjiang in an all-round way. And through the precipitation in Heilongjiang, it extended to China as a whole. The establishment of these music schools has laid a foundation for the enlightenment and training of professional music management personnel and music creation personnel. It created a strong musical atmosphere in the social environment of Heilongjiang at that time. A large number of music performers have been trained. It has played an immeasurable role in promoting the development of modern professional music in China.

\section{Conclusions}

Since the 20th century, due to special historical and geographical reasons, Heilongjiang music culture has been deeply influenced by Russian music culture. These influences not only have a great impact on Heilongjiang music culture, but also have played an important role in promoting China's acceptance of modern western music culture. Use. To conclude and summarize this historical and cultural phenomenon is of great significance for promoting the study of the origin and development of music culture in Heilongjiang and deepening the systematic construction of "one belt and one road" culture.

\section{Acknowledgments}

Topic: A Study on the Multidimensional Impact of Russian Music Culture on Harbin City Music Culture in the 20th Century

Source: Heilongjiang Philosophy and Social Science Research Planning Project

Issue number: 18YSE620 


\section{References}

[1] Cui Jiayue. The Influence of Russian Music on the Development of Harbin Music Culture [J]. Art Education, 2017, (01).

[2] Gao Yansong. Contribution and influence of Russian musicians to Chinese music from the 19th to the mid-20th century [D].Harbin: Harbin Normal University, 2011.

[3] Wang Qi. The Promoting Role of Russian Music Culture in the 20th Century on the Development of Heilongjiang Music [J].Music Space-time, 2016, (07).

[4] Li Xiaoying. The Influence of Russian Music Education on Chinese Music Education - The First Half of the 20th Century [J].Frontier Economy and Culture, 2011, (11).

[5] Liu Feng. Development of Western Conservatories of Music before 1945 and its impact on professional music education in China [J].Symphony. Journal of Xi'an Conservatory of Music, 2005, (03). 